\title{
Analysis of the relation between intelligence and criminal behavior
}

\author{
Dragan Jovanovic ${ }^{1}$, Milan Novakovic ${ }^{2}$, Aleksandra Salamadić ${ }^{1}$, Novica Petrovic ${ }^{1}$, Sanja Maric ${ }^{3}$ \\ ${ }^{1}$ Faculty of Medicine Foca, University of East Sarajevo and Neuropsychiatry Department, University Hospital Foca, Studentska \\ 5, Foča Bosnia and Hercegovina. ${ }^{2}$ Faculty of Medicine Foca, University of East Sarajevo, Studentska 5, Foča, Bosnia and \\ Hercegovina. ${ }^{3}$ Faculty of Medicine Foca, University of East Sarajevo, University Hospital Foca, Anaesthesiology and Reanimation \\ Department, Studentska 5, Foča, Bosnia and Hercegovina
}

\begin{abstract}
Introduction: One of the cognitive aspects of personality is intelligence. A large number of previous studies have shown that the intelligence within the criminal population is decreased, particularly in its verbal aspect. The aim of this study is to determine whether there is a link between intelligence and criminal behavior and how it is manifested.

Methods: The research involved criminal inmates of the Correctional institutes of Republic of Srpska and Court Department of Psychiatry Clinic Sokolac who committed homicide and various non-homicide acts. The test group consisted of 60 inmates who have committed homicide (homicide offenders) and a control group of 60 inmates who did not commit homicide (non-homicide offenders). The study was controlled, transverse or cross-sectional study.

Results: Average intelligence of inmates (homicidal and non-homicidal) was IQ 95.7. Intelligence of homicide inmates was IQ 97.4 and non-homicide IQ 94.09. Intelligence coefficients for non-homicide inmate subgroups were as follows - subgroup consisting of robbery offenders (IQ 96.9), subgroup consisting of theft perpetrators (IQ 93.83), subgroups consisting of other criminal offenders (IQ 92.8). Verbal intellectual ability - IQw of homicide inmates was 91.22, and 91.10 IQw of non-homicide inmates. Intellectual abilities in nonverbal or manipulative part were average, but they were higher in homicide inmates group (IQm 103.65) than in the group of non-homicide inmates (IQm 97.08).

Conclusion: Average intelligence of investigated inmates (homicide and non-homicide) is lower than in the general population and corresponds to low average. Verbal part of intelligence is lowered while nonverbal part is within the average range.

(C) 2012 All rights reserved
\end{abstract}

Keywords: Analysis, intelligence, criminals, criminal behavior.

\section{Introduction}

An individual has all the characteristics of a person, its uniqueness and individuality, which makes it different from all the others. Personality is formed in the interaction of heredity and external environment. By the word of $\mathrm{HJ}$ Eysenck: "Personality is more or less solid organization of character, temperament, intellect and physical constitution"(1-3). Intelligence in its essence is constitutionally and genetically defined capacity, but it is also to a large extent shaped by the envi-

\footnotetext{
* Corresponding author: Prim. Dr. Dragan Jovanovic, MD, PhD

Faculty of Medicine, Foca, University of East Sarajevo Studentska 5, 73300 Foca, Bosnia and Hercegovina. Phone: 065987 685; E-mail: drdragan@teol.net
}

Submitted 3 November 2012 / Accepted 7 December 2012 ronment (by upbringing and education and possibility of flow of information). It is defined as a complex ability to assimilate factual knowledge; to respond to logical and to manipulate concepts, to translate literally to abstract, to cope meaningfully and clearly with problems and priorities assessed and valued as important in certain situation, the ability to solve new problems and mentally adapt to new roles. It is defined as the capacity for learning and usage of things learned $(3,5,6)$. NMR studies associate the brain of violent criminals diagnosed with psychopathy, their emotional and cognitive deficits, with a reduced orbitofrontal areas of the brain as well as abnormalities of amygdala nuclei (4). Numerous studies prove that the intelligence of de- 
linquents is lower in comparison with the general population. We can even see the differences between groups of delinquents. Lowest intelligence is associated with groups of violent offenders. Delinquents achieve lowest score in the area of verbal ability and abstract reasoning, while in terms of other cognitive abilities they don't fall behind in comparison to the general population (5-11). Sample of 370 inmates convicted for non-sexual violent offenses proved that convicts with no diagnosis of psychopathy have higher overall coefficient of intelligence, as well as in its verbal part, from those having this diagnosis. The study proves that non psychopaths start much later with criminal activities (12). Linkage of lower intelligence with criminal behavior is explained in various ways: low intelligence leads to poor school performance and those who fail in school are less likely to succeed in life and will probably resort to delinquent behavior. School failure, the frustration that causes uncomfortable feelings lead to a drop in self-esteem, and it may already be sufficient cause for delinquent behavior apart in drop in verbal skills which are important for communication that can be used to solve many problems. People of low verbal ability are having hard time coping with various social situations which at some point can be the impetus for delinquent behavior; persons of low verbal abilities find it hard to adopt the moral standards of society (6-13). We compared the samples of juvenile delinquents and non-delinquentsandfound that the delinquents had pronounced impairment of cognitive abilities (the lag in verbal abilities) than non-delinquents. We also showed that delinquents present conative disorders of depressive and obsessive type (6-13). Impulsivity is one of the main reasons behind committing crimes by mentally retarded persons as well as their suggestibility paired with insufficient understanding of moral rules and the possibility of learning from experience. Increased suggestibility of mentally retarded people, in addition to committing criminal acts, has a profound effect on making false confessions. The most common forms of criminal offenses among mentally retarded persons were property crimes (theft, robbery and burglary), sexual offenses, violent offenses (murder and causing grievous bodily harm) and intentional arson (6-13).
Dementia can be associated with delinquent behavior in terms of harmful behaviors of demented people to himself and to others. As a result of severe memory impairment and confusion demented people can cause fires, and as a result of delusional ideas of persecution and emotional instability they can hurt or even kill another person (6-13). The aim of this study is to determine whether there is a correlation between intelligence and criminal behavior and how these linkages are manifested.

\section{Methods}

Research involved the inmates of correctional institutes from the Republic of Srpska (KPZ "Tunjice") Banja Luka, Prison "Kula" of Eastern Sarajevo, (Foca prison) and the Court Department of the Psychiatry Clinic Sokolac. A total of 105 inmates who had committed suicide and 100 resident perpetrators of non-homicide acts have been examined. 15 inmates who have been convicted on the issue of war crimes (war criminals were not covered by our study) were excluded from the group as well as 30 inmates for incompletely and incorrectly completion of psychological tests. Exclusion from the group of non-homicidal inmates was performed due to excessive link between criminal acts with war situations (12 inmates) as well as because of incomplete and / or incorrectly completed psychological tests (28 inmates). After these exclusions, test group was formed consisting of homicide persons (murderers)- 60 inmates and a control group of non-homicide persons(non murderers), also 60 inmates. The control group was formed from the perpetrators of robbery $(\mathrm{N}=22)$, theft $(\mathrm{N}=18)$ and other offenses $(\mathrm{N}=20)$. In the subgroup of non-homicide perpetrators of other crimes were the perpetrators of illegal production and traffic of drugs $(\mathrm{N}=7)$, endangering public transportation $(\mathrm{N}=4)$, rape $(\mathrm{N}=3)$, tax evasion $(\mathrm{N}=2)$, illicit production and trade of weapons and explosive devices $(\mathrm{N}=1)$, counterfeiting $(\mathrm{N}$ $=1)$, sexual child abuse $(\mathrm{N}=1)$ and fraud $(\mathrm{N}=1)$. Subjects in the test group and the control group approached to the research on a voluntary basis. The study was controlled, transverse (cross-sectional study). Intelligence tests, verbal and nonverbal, were used for the purposes of exploration of problem as well as exploration of objectives of study. Verbal intelligence test was informative test 
consisting of twenty questions on which inmates answered textually. Questions were tailored to various levels of education and in the domain of the various scientific fields. Nonverbal or manipulative intelligence test was the Revised Beta test consisting of six subtests. Intellectual skills assessed on the basis of these intelligence tests were expressed using intelligence coefficients (IQ):

1) IQ 70 and $<-$ defective intelligence

2) IQ 71-79 - low

3) IQ 80-89 - below average

4) IQ 90-109 - average

5) IQ 110 -119 - above average

6) IQ $120-128$ - high

7) IQ of 129 -> - very high

\section{Statistical analysis}

characteristics observed in the study were subjected to descriptive statistical methods - measures of central tendency (mean, median, minimum, maximum, measures of variability (standard deviation) and relative numbers as indicators of the structure. In order to make relevant conclusions, notable differences between groups were analyzed by param- eter (Student's t-test) and non parameter (Fisher, Pearson Chi-Square - chi-square test, Mann-Whitney U test, Kolmogorov-Smirnov Z-test) statistical methods. Using statistical methods (ANOVA - analysis of variance and LSD - test least significant difference), differences between the groups and subgroups of homicide and non-homicide inmates were analyzed (subgroup perpetrators of robbery, theft perpetrators subgroup and subgroup of perpetrators of other crimes). Results of statistical analysis were presented in tabular form.

\section{Results}

Spreadsheet of statistical analysis of the results of psychological processing of nonverbal and verbal intelligence tests of experimental and control groups is presented. Intergroup differences test(t-test) shows that there is a statistically significant difference between the groups on nonverbal intelligence tests $\mathrm{T} 2$, a highly statistically significant difference in non verbal test $\mathrm{T} 4$, and a highly statistically significant difference in the overall non-verbal (manipulative) intelligence test- nonverbal intelligence coefficient of homicide inmates (IQm 103.65) and non non-homicide (IQm 97.8).

TABLE1 Non-verbal tests (T 1 - T 6), verbal intelligence tests - descriptive statistics and intergroup differences test (T-test).

\begin{tabular}{|c|c|c|c|c|c|c|c|c|}
\hline \multicolumn{5}{|c|}{ Descriptive statistical data } & \multicolumn{4}{|c|}{ T-test } \\
\hline Test & Group & $\mathrm{N}$ & Mean & SD & $t$ & df & $P$ & Mean diff. \\
\hline \multirow{2}{*}{ T 1 Non verb. } & Homicide & 60 & 13.05 & 2.49 & -1.003 & 118 & 0.318 & -0.5000 \\
\hline & Non homicide & 60 & 12.55 & 2.95 & & & & \\
\hline \multirow{2}{*}{ T 2 Non verb. } & Homicide & 60 & 12.70 & 2.24 & -2.173 & 118 & 0.032 & -1.050 \\
\hline & Non homicide & 60 & 11.65 & 3.00 & & & & \\
\hline \multirow{2}{*}{ T3 Non verb. } & Homicide & 60 & 9.65 & 1.96 & 0.591 & 118 & 0.556 & 0.216 \\
\hline & Non homicide & 60 & 9.87 & 2.05 & & & & \\
\hline \multirow{2}{*}{ T 4 Non verb. } & Homicide & 60 & 10.33 & 1.99 & -3.137 & 118 & 0.002 & -1.266 \\
\hline & Non homicide & 60 & 9.07 & 2.41 & & & & \\
\hline \multirow{2}{*}{ T 5 Non verb. } & Homicide & 60 & 10.70 & 2.40 & -1.434 & 118 & 0.154 & -0.683 \\
\hline & Non homicide & 60 & 10.02 & 2.80 & & & & \\
\hline \multirow{2}{*}{ T 6 Non verb. } & Homicide & 60 & 5.35 & 4.48 & -1.744 & 118 & 0.084 & -1.300 \\
\hline & Non homicide & 60 & 4.05 & 3.65 & & & & \\
\hline \multirow{2}{*}{ Iqm } & Homicide & 60 & 103.65 & 10.83 & -3.191 & 118 & 0.002 & -6.566 \\
\hline & Non homicide & 60 & 97.08 & 11.70 & & & & \\
\hline \multirow{2}{*}{ Iqw } & Homicide & 60 & 91.22 & 14.61 & -0.043 & 118 & 0.966 & -0.116 \\
\hline & Non homicide & 60 & 91.10 & 15.29 & & & & \\
\hline
\end{tabular}

$\mathrm{N}$ - number of respondents, the Mean - the mean value, $\mathrm{t}$ - value of T-test, df - degree of freedom, $\mathrm{P}$ - probability, Mean diff - differences in mean values. 
Analysis of variance showed a statistically signifi- T6 nonverbal intelligence tests, as well as the overcant difference between the groups in T 3, T 5 and all IQm (nonverbal or manipulative intelligence

TABLE2. ANOVA (analysis of variance) - statistical analysis of intergroup, intragroup and total variability in verbal and nonverbal intelligence tests.

\begin{tabular}{|c|c|c|c|c|c|c|}
\hline Test & Variability & Sum of squares & $\mathrm{df}$ & Mean square value & $\mathrm{F}$ variant quotient & $\mathrm{P}$ \\
\hline \multirow{3}{*}{ Test 1} & Intergroup & 15,356 & 3 & 5.119 & 0.681 & 0.565 \\
\hline & Intragroup & 871.844 & 116 & 7.516 & & \\
\hline & Total & 887.200 & 119 & & & \\
\hline \multirow{3}{*}{ Test 2} & Intergroup & 90.152 & 3 & 30.051 & 4.532 & 0.005 \\
\hline & Intragroup & 769.173 & 116 & 6.631 & & \\
\hline & Total & 859.325 & 119 & & & \\
\hline \multirow{3}{*}{ Test 3} & Intergroup & 34.241 & 3 & 11.414 & 2.984 & 0.034 \\
\hline & Intragroup & 443.751 & 116 & 3.825 & & \\
\hline & Total & 477992 & 119 & & & \\
\hline \multirow{3}{*}{ Test 4} & Intergroup & 50.131 & 3 & 16.710 & 3.371 & 0.21 \\
\hline & Intragroup & 575.069 & 116 & 4.957 & & \\
\hline & Total & 625.200 & 119 & & & \\
\hline \multirow{3}{*}{ Test 5} & Intergroup & 53.351 & 3 & 17.784 & 2.699 & 0.049 \\
\hline & Intragroup & 764.241 & 116 & 6.588 & & \\
\hline & Total & 817.592 & 119 & & & \\
\hline \multirow{3}{*}{ Test 6} & Intergroup & 115.432 & 3 & 38.477 & 2.347 & 0.076 \\
\hline & Intragroup & 1901.768 & 116 & 16.395 & & \\
\hline & Total & 2017.200 & 119 & & & \\
\hline \multirow{3}{*}{$\mathrm{IQm}$} & Intergroup & 1503.125 & 3 & 501.042 & 3.932 & 0.010 \\
\hline & Intragroup & 14780.741 & 116 & 127.420 & & \\
\hline & Total & 16283.867 & 119 & & & \\
\hline \multirow{3}{*}{ IQw } & Intergroup & 125.346 & 3 & 41.782 & 0.185 & 0.907 \\
\hline & Intragroup & 26266.646 & 116 & 226.437 & & \\
\hline & Total & 26391.992 & 119 & & & \\
\hline
\end{tabular}

TABLE3. . Structure IQw (verbal intelligence coefficient) for each group of inmates with regard to the type of crime

\begin{tabular}{|c|c|c|c|c|c|c|c|}
\hline $\mathrm{IQ}$ & Value IQV & & & & I offense & & \\
\hline \multirow{13}{*}{$\begin{array}{l}\text { Verbal } \\
\text { Intelligence } \\
\text { Quotient } \\
\text { IQw }\end{array}$} & & & Robbery & Theft & Other offenses & Murderers & Iotal \\
\hline & \multirow{2}{*}{$<70$} & Number & 1 & 2 & 1 & 5 & 9 \\
\hline & & $\%$ & $4.5 \%$ & $11.1 \%$ & $5.0 \%$ & $8.3 \%$ & $7.5 \%$ \\
\hline & \multirow{2}{*}{$71-79$} & Number & 3 & 5 & 4 & 11 & 23 \\
\hline & & $\%$ & $13.6 \%$ & $27.8 \%$ & $20.0 \%$ & $18.3 \%$ & $19.2 \%$ \\
\hline & \multirow{2}{*}{$80-89$} & Number & 4 & 2 & 3 & 8 & 17 \\
\hline & & $\%$ & $18.2 \%$ & $11.1 \%$ & $15.0 \%$ & $13.3 \%$ & $14.2 \%$ \\
\hline & \multirow{2}{*}{$90-109$} & Number & 11 & 7 & 9 & 31 & 58 \\
\hline & & $\%$ & $50.0 \%$ & $38,9 \%$ & $45.0 \%$ & $51.7 \%$ & $48.3 \%$ \\
\hline & \multirow{2}{*}{$110-119$} & Number & 3 & 2 & 2 & 5 & 12 \\
\hline & & $\%$ & $13,6 \%$ & $11,1 \%$ & $10 \%$ & $8.3 \%$ & $10.0 \%$ \\
\hline & \multirow{2}{*}{$120-128$} & Number & 0 & 0 & 1 & 0 & 1 \\
\hline & & $\%$ & $0 \%$ & $0 \%$ & $5.0 \%$ & $0 \%$ & 0.83 \\
\hline \multirow{2}{*}{ Total } & & Number & 22 & 18 & 20 & 60 & 120 \\
\hline & & $\%$ & $100 \%$ & $100 \%$ & $100 \%$ & $100 \%$ & $100 \%$ \\
\hline
\end{tabular}


coefficient), as well as high statistically significant difference in the T 2 nonverbal intelligence test. The least significant difference test (LSD test). Multiple intergroup comparisons by the means of least significant difference test(LSD test) showed that there is: a statistically significant difference between subgroups of non-homicide perpetrators of theft and other subgroups of non-homicide perpetrators of crimes, as well as between groups of perpetrators of killings and other subgroups of non-homicide perpetrators of crimes on the T 2 nonverbal intelligence test; statistically significant differences between subgroups of non-homicide perpetrators of robbery and subgroups of nonhomicide perpetrators of other crimes, as well as a highly statistically significant difference between subgroups of non-homicide perpetrators of theft and subgroups of non-homicide perpetrators of other crimes in the T 3 nonverbal intelligence test; a statistically significant difference between subgroups of non-homicide robbery perpetrators and a group of killers as well as group of murderers and subgroups of non-homicide perpetrators of theft in T 4 nonverbal intelligence test; a statistically significant difference between subgroups of non-homicide perpetrators of theft and subgroups of non-homicide perpetrators of other crimes, as well as between groups of murderers and subgroup of non-homicide perpetrators of other crimes in the $\mathrm{T} 5$ nonverbal intelligence test; statistically significant differences between subgroups of non-homicide perpetrators of theft and subgroups of non-homicide perpetrators of other crimes as well as between groups of murderers and subgroups of non-homicide perpetrators of other crimes, and a highly significant difference between the groups of murderers and subgroups of non-homicide perpetrators of oth-

TABLE4. Testing the significance of difference in coefficients of verbal intelligence $(I Q w)$ between groups of inmates with regard to the type of crime by means of factorial analysis of varianceranks (Kruskal-Wallis test)

\begin{tabular}{lllllll}
\hline IQ & Type of crime & $\mathrm{N}$ & Mean rank value & $\mathrm{X}^{2}$ - Chi-square & df & $\mathrm{P}$ \\
\hline \multirow{3}{*}{ Verbal } & Robbery & 22 & 65.27 & 1.349 & 3 & 0.717 \\
Intelligence & Theft & 18 & 54.08 & & & \\
coefficient & Other & 20 & 63.28 & & \\
IQw & Murderers & 60 & 59.75 & & \\
& Total & 120 & & & & \\
\hline
\end{tabular}

TABLE 5. Structure of IQm (non-verbal or manipulative intelligence coefficient) for each group of inmates with regard to the type of crime

\begin{tabular}{|c|c|c|c|c|c|c|c|}
\hline \multirow[t]{2}{*}{$\begin{array}{l}\mathrm{IQ} \text { - Intelligence } \\
\text { coefficient. }\end{array}$} & \multirow[t]{2}{*}{ Value Iqm } & & \multicolumn{4}{|c|}{ Type of crime } & \multirow[t]{2}{*}{ Total } \\
\hline & & & Robbery & Theft & Other & Murderers & \\
\hline \multirow{12}{*}{$\begin{array}{l}\text { Non verbal } \\
\text { Intelligence } \\
\text { coefficient } \\
\text { IQm }\end{array}$} & \multirow{2}{*}{$<70$} & Number & 0 & 0 & 0 & 0 & 0 \\
\hline & & $\%$ & $0 \%$ & $0 \%$ & $0 \%$ & $0 \%$ & $0 \%$ \\
\hline & \multirow{2}{*}{$71-79$} & Number & 2 & 3 & 2 & 1 & 8 \\
\hline & & $\%$ & $9.09 \%$ & $16.66 \%$ & $10.00 \%$ & $1.66 \%$ & $6.66 \%$ \\
\hline & \multirow{2}{*}{$80-89$} & Number & 2 & 1 & 5 & 5 & 13 \\
\hline & & $\%$ & $9.09 \%$ & $5.55 \%$ & $25.00 \%$ & $8.33 \%$ & $10.83 \%$ \\
\hline & \multirow{2}{*}{$90-109$} & Number & 15 & 11 & 12 & 32 & 70 \\
\hline & & $\%$ & $68.18 \%$ & $61.11 \%$ & $60.00 \%$ & $53.33 \%$ & $58.33 \%$ \\
\hline & \multirow{2}{*}{$110-119$} & Number & 2 & 2 & 1 & 17 & 22 \\
\hline & & $\%$ & $9.09 \%$ & $11.11 \%$ & $5.00 \%$ & 28.33 & $18.33 \%$ \\
\hline & \multirow{2}{*}{$120-128$} & Number & 1 & 1 & 0 & 5 & 7 \\
\hline & & $\%$ & $4.54 \%$ & $5.55 \%$ & $0 \%$ & $8.33 \%$ & $5.83 \%$ \\
\hline \multirow{2}{*}{ Total } & & Number & 22 & 18 & 20 & 60 & 120 \\
\hline & & $\%$ & $100 \%$ & $100 \%$ & $100 \%$ & $100 \%$ & $100 \%$ \\
\hline
\end{tabular}


TABLE 6. Testing the IQm significance of difference between all groups and sub-groups of inmates using factorial analysis of variance ranks (Kruskal-Wallis test)

\begin{tabular}{lllllll}
\hline IQ & Type of crime & $\mathrm{N}$ & Mean ranks value & $\mathrm{X}^{2}$ - Chi-Square & $\mathrm{df}$ & $\mathrm{P}$ \\
\hline Non verbal or & Robbery & 22 & 55.32 & 12.944 & 3 & 0.005 \\
manipulative & Theft & 18 & 54.36 & & \\
intelligence & Other & 20 & 43.55 & & \\
coefficient & Murderers & 60 & 69.89 & & \\
IQm & Total & 120 & & & & \\
\hline
\end{tabular}

TABLE7. Testing the significance of IQm differences between subgroups of non-homicide inmates considering the type of crime committed using Kruskal-Wallis test.

\begin{tabular}{lllllll}
\hline IQ & Type of crime & $\mathrm{N}$ & Mean ranks value & $\mathrm{X}^{2}$ - Chi-square & $\mathrm{df}$ & $\mathrm{P}$ \\
\hline Manipulative or & Robbery & 22 & 32.73 & 1.869 & 2 & 0.393 \\
non verbal & Theft & 18 & 31.92 & & \\
intelligence & Other & 20 & 26.78 & & \\
coefficient & Total & 60 & & & \\
IQm & Total & 120 & & & \\
\hline
\end{tabular}

er crimes in the T 6 nonverbal intelligence test. There was high percentage of inmates with belowaverage verbal intellectual abilities in all groups - subgroup of non-homicide robbery offenders $36.3 \%$, with $4.5 \%$ of mental defective individuals, the subgroup of non-homicide theft perpetrators $50.00 \%$, with as much as $11.1 \%$ of the defective persons, a subset of non-homicide perpetrators of other offenses $40 \%$ with $5 \%$ defective persons and perpetrators of the murder group 39.9\%, with $8.3 \%$ of mental defective persons. There was an average of $7.5 \%$ of mental defective inmates in terms of verbal intelligence coefficient. Test showed no statistically significant differences between groups of inmates in terms of verbal IQ with regard to the type of crime committed. Manipulative or nonverbal intellectual abilities were larger than the verbal ones in all groups and subgroups. Kruskal-Wallis test shows that there is a statistically significant difference between groups of inmates, according to type of criminal offense in terms of nonverbal intelligence coefficient.

Kruskal-Wallis test showed no statistically significant difference in terms of nonverbal intelligence coefficient between subgroups of non-homicide inmates, considering the type of crime committed.

\section{Discussion}

Average total intelligence number in all investigated inmates (homicide and non-homicide) was IQ
95.7, corresponding to a deviation toward a low average. Overall intelligence coefficient for homicide inmates was IQ 97.4 and 94.09 for non-homicidal. Intelligence coefficient for subgroups of non-homicide inmates was as follows: subgroup robbery offenders (IQ 95.4), subset of the perpetrators of theft (IQ 93.83) and other criminal offender's subgroups (IQ 92.8). According to these data, the highest reduction in overall intellectual ability was observed in subgroups of non-homicide theft offenders and perpetrators of other crimes which were, perhaps, related to the easier identification of the crimes committed and the weaker ability to hide the crime by inmates from this subgroup. It is evident that intellectual abilities in non-verbal or manipulative part were average, but they were higher in homicide inmates (IQm 103.65) than in the group of non-homicide (IQm 97.08) - perpetrators of the robbery (IQm 98.22), theft (IQm 98.61) and other criminal acts (IQm 94.45). IQm average for all inmates was 100 . At the same time, verbal intellectual ability (IQw) was lower than the average in relation to the general population and it was in low level of the average (homicide inmates 91.22 IQw and non-homicide IQw 91.10), which generally agrees with previous studies showing that violent offenders have lower verbal intellectual abilities compared to the general population (5-13). Particularly striking was the high percentage (40-50\%) of inmates with below-average verbal 
intellectual abilities. Profile of verbal intelligence coefficient indicated lower verbal intellectual abilities from the average in the general population because of the high percentage of inmates with below-average verbal intellectual abilities. This was most pronounced in the subgroup of theft perpetrators - 50\% with below-average verbal intelligence coefficient followed by a subgroup of non-homicide perpetrators of other crimes with $40 \%$, homicide inmates group with $39.9 \%$ and subgroups of non-homicide perpetrators of robbery with $36.3 \%$ of the perpetrators with a below-average verbal intelligence coefficient. In addition, the homicide inmate group, five $(8.33 \%)$ had verbal intelligence coefficient on the level of defective intelligence, and in group of non-homicide inmates, four $(6.66 \%)$ of them had aforementioned verbal intellectual abilities. Profile of non-verbal or manipulative intelligence coefficient was performed within groups of inmates with regard to the type of crime that showed that non-verbal or manipulative abilities in all groups were larger than verbal, i.e., there were lower percentage of inmates with below-average nonverbal intellectual coefficient - a group of homicide inmates $17.49 \%$, non-homicide robbery offenders subgroup $18.18 \%$, subgroup of non-homicide theft perpetrators $22: 21 \%$ and subgroup of non-homicide perpetrators of other crimes $35 \%$ of inmates with below-average nonverbal intellectual abilities. At the same time it was found that $13.6 \%$ of robbery offenders, $16.6 \%$ perpetrators of theft, $5 \%$ of the perpetrators of other offenses and 36\% of homicide offenders had above average nonverbal or manipulative intelligence coefficient. According to the literature, lower verbal intellectual abilities may be due to lower levels of education, but they may exist before going to school and be a result of neurophysiologic deficit. Reduced intel- lectual ability, particularly decreased verbal intelligence factor, can have a significant impact on the development of delinquent properties of inmates. Lower intelligence lead to poor school performance and people who fail in school are less likely to succeed in life so they easily resort to delinquent behavior. Failure in school is a strong frustration that can lead to the occurrence of aggression and criminal behavior. People with reduced verbal communication skills are weak and disoriented in various social situations, which can lead to the development of delinquent behavior. People with low verbal abilities find it hard to adopt the norms of morality and recourse to asocial or even delinquent actions. Verbal skills are important in the control of behavior, that is, the ability to connect potential reactions with potential consequences. Poor academic performance and low educational level and thus the weaker verbal abilities have its roots in asocial-psychopathic features that are prominent in the group of homicide inmates, which has been proven in research. Better performance on nonverbal or manipulative part probably provides skill in some types of delinquency (5-13).

\section{Conclusion}

Average intelligence of investigated inmates (homicide and non-homicide) is lower than in the general population. Homicide inmate's intelligence was shown to be slightly greater than nonhomicide group. Intellectual skills were average in verbal or manipulative part, but were more pronounced in the homicide group than in the nonhomicide group. Verbal intellectual abilities were lower than average for the general population and they were in lower border range in both groups.

\section{Competing interests}

Authors declare no competing interests.

\section{References}

[1] Kaličanin P. Psihijatrija. Beograd:Velarta; 1997. str. 119120.

[2] Kecmanović D. Psihijatrija. Medicinska knjiga BeogradZagreb; 1989. str. 1238-1242.

[3] Jašović Gašić M, Lečić Toševski D. Psihijatrija. Udžbenik za studente medicine. Beograd: Univerzitet u Beogradu, Medicinski fakultet; 2007. str. 196-204.
[4] Boccardi M, Frisoni N, Hare R, Cavedo E, Najt P, Pievani M. et al. Cortex and amygdala morphology in psychopathy. Psychiatry Res 2011;193(2):85-92.

[5] Mejovšek M. Uvod u penološku psihologiju. Naklada Slap - Jastrebarsko i Edukacijsko - Rehabilitacijski Fakultet Sveučilišta u Zagrebu; 2002.

[6] Moffit TE, Lynam DR, Silva PA. Neuropsychological tests 
predicting persisting male delinquency. Criminology 1994;32:277-300.

[7] Kljajić S, Prišlin R. Struktura rezultata u verbalnim i neverbalnim testovima WISC kod delinkventne djece. Primijenjena psihologija 1984;5:1-6.

[8] Stattin H, Klackenberg-Larsson I. Early language and intelligence development and their relationship to future criminal behaviour. J Abnorm Psychol 1993 Aug;102(3):369-378.

[9] Momirović K, Viskić-Štalec N, Mejovšek M. Relacije kognitivnih i konativnih karakteristika maloljetnih delinkvenata i efikasnosti resocijalizacije nakon penalnog tretmana. Defektologija 1974;10:155-173.
[10] Kovačević V, Momirović K, Singer M. Razlike u strukturi ličnosti između delinkventne i nedelikventne populacije. Defektologija 1971;7:3-8.

[11] Kovač M, Žarković Palijan T, Kovačević D, Mustapić J. Neubrojivi mentalno retardirani počinitelji kaznenog djela. KD Polic Sigur Zagreb 2008;1-2:90-100.

[12] Guay JP, Ouimet M, Proulks J. On intellingence and crime: A comparison of incarcerated sex offenders and serious non-sexual violent criminals.Int J Law Psychiat. 2005;28:405-17.

[13] Kennedy TD, Burnett KF, Edmonds WA. Intellectual, behavioral, and personality correlates of violent vs. nonviolent juvenile offenders. Agress. Behav. 2011;37:315-25. 